13. Kravchenko, O.M. \& Gramm, O.M. (2012). Ethical aspect of the culture of library service. Fourth International Scientific and Practical Conference "Modern Problems of the Library's Activities in the Information Society". Lviv, Ukraine. 513-522 [in Ukrainian]. Ukrainian].

14. Code of professional ethics of Ukrainian antiquaries. Retrieved from http://ua.gau.kiev.ua/about/codex. [in

15. Hrytsuta, N. (2014). Professional ethics of PR-activity: the essence of the concept, principles. State and regions. Series: Social Communications, 4, 130-135. [in Ukrainian].

16. Senyuk, A.S. (2007). Ethical aspect of professional standards of Ukrainian and foreign journalism. Culture of the Black Sea peoples, 101, 143-146. [in Ukrainian].

17. Code of ethics of the Ukrainian journalist (2013, October). Retrieved from http://uju.rv.ua/en/codex.html. [in Ukrainian].

Стаття надійшла до редакції 22.07.2019 p.

Удк 7.071.2:37.013.43

Косінова Олена Миколаївна

кандидат педагогічних наук, доцент,

заслужена артистка України

ORCID 0000-0002-2569-8762

kosinova@meta.ua

\title{
ХАРАКТЕРИСТИКА ПЕДАГОГІЧНОГО СПІЛКУВАННЯ І ЙОГО ЗНАЧЕННЯ ДЛЯ ФОРМУВАННЯ КОРПОРАТИВНОЇ КУЛЬТУРИ ТЕЛЕЖУРНАЛІСТІВ
}

Мета роботи - розкрити сутність процесу упровадження корпоративної культури в системі естетичної спрямованості професійної підготовки телеведучих. Методологія дослідження передбачає комплексний підхід із застосуванням аналітичного, системного методів, компаративного, що дозволяє зрозуміти, що ідеал мистецької освіти потребує змістовного наповнення, створення оптимальних умов для корпоративної культури в системі естетичного життя студентів вишу культури і мистецтв. Наукова новизна роботи полягає в актуалізації концепту корпоративної культури у контексті та зв'язку з фрормуванням професійної підготовки телеведучих. Висновки. В результаті проведеного дослідження встановлено, що в умовах творчого вишу впровадження естетичної спрямованості професійної підготовки студентів здійснюється шляхом формування особистості митця з гармонійно поєднаними професійними, морально-естетичними, психологічними якостями і забезпечується цілеспрямованою навчально-виховною діяльністю. Найважливішими естетичними якостями в процесі формування корпоративної складової естетичної підготовки майбутніх телеведучих є такі: повага до історії, культури, гідності, етичних ідеалів кожного народу; інтерес до національної мови, звичаїв, традицій, а також наявність почуттів взаємної толерантності та делікатності як стосовно національно «іншого» менталітету, духовних цінностей, так і носіїв іншої культури та думок , що не співпадають з власними.

Ключові слова: корпоративна культура, естетична спрямованість, інформаційне суспільство, творча діяльність, культурна спадщина, естетичний смак, естетичне життя.

Косинова Елена Николаевна, кандидат педагогических наук, доцент заслуженная артистка Украины Характеристика педагогического общения и его значение для формирования общественной корпоративной культуры тележурналистов

Цель работы - раскрыть сущность процесса внедрения корпоративной культуры в системе эстетической направленности профессиональной подготовки телеведущих. Методология исследования предполагает комплексный подход с применением аналитического, системного методов, компаративного, что позволяет понять, что идеал художественного образования требует содержательного наполнения, создание оптимальных условий для корпоративной культуры в системе эстетического жизни студентов вуза культуры и искусств. Научная новизна работы заключается в актуализации концепта корпоративной культуры в контексте и связи с формированием профессиональной подготовки телеведущих. Выводы. В результате проведенного исследования установлено, что в условиях творческого вуза внедрения эстетической направленности профессиональной подготовки студентов осуществляется путем формирования личности художника с гармонично соединенными профессиональными, морально-эстетическими, психологическими качествами и обеспечивается целенаправленной учебновоспитательной деятельностью. Важнейшими эстетическими качествами в процессе фрормирования корпоративной составляющей эстетической подготовки будущих телеведущих являются: уважение к истории, культуре, достоинства, этических идеалов каждого народа, интерес к национальному языку, обычаям, традициям, а также наличие чувств взаимной толерантности и деликатности как относительно национально «другого» менталитета, духовных ценностей, так и носителей другой культуры и мыслей, которые не совпадают с собственными.

Ключевые слова: корпоративная культура, эстетическая направленность, информационное общество, творческая деятельность, культурное наследие, эстетический вкус, эстетическое жизни.

Kosinova Olena, Candidate of Pedagogical Sciences, assistant professor, Honored Artist of Ukraine Characteristics of pedagogical communication and its importance for corporate culture director

The purpose of the work is to reveal the essence of the process of introduction of corporate culture in the system of aesthetic orientation of professional training of TV presenters. The research methodology involves a

() Косінова О. М., 2019 
comprehensive approach with the use of analytical, systematic, and comparative methods, which makes it clear that the ideal of art education needs a meaningful content, creating optimal conditions for corporate culture in the system of aesthetic life of students of higher education and arts. The scientific novelty of the work lies in updating the concept of corporate culture in the context and in connection with the formation of professional training of broadcasters. Conclusions. As a result of the conducted research it is established that in the conditions of creative higher education the implementation of the aesthetic orientation of professional training of students is carried out by forming the personality of the artist with harmoniously combined professional, moral and aesthetic, psychological qualities and is provided with purposeful educational activities. The most important aesthetic qualities in the process of forming the corporate component of the aesthetic preparation of future TV presenters are the following: respect for the history, culture, dignity, ethical ideals of each people; interest in the national language, customs, traditions, as well as feelings of mutual tolerance and delicacy as to the national "other" mentality, spiritual values, and carriers of another culture and opinions that do not coincide with one's own.

Keywords: corporate culture, aesthetic orientation, information society, creative activity, cultural heritage, aesthetic taste, aesthetic life.

Актуальність теми дослідження. Становлення сучасної професійної освіти потребує створення соціально-педагогічних умов гуманізації особистості майбутнього тележурналіста, оскільки мистецькі професіонали є потужним потенціалом розвитку нашого суспільства. Такі умови можна створити лише при наявності у студентів системного мислення, духовності та високого рівня корпоративної культури, відповідальності за майбутнє, що проявляється у професійному спілкуванні.

Сучасна наука все більше схиляється до думки, що спілкування, як об'єктивний вид життєдіяльності кожної особистості, виступає своєрідним мистецтвом, де є свої правила, свої особливості, свої секрети, знати які потрібно кожному спеціалісту для оптимізації своєї діяльності, досягнення мети.

Мета роботи - розкрити сутність процесу упровадження корпоративної культури в системі естетичної спрямованості професійної підготовки телеведучих.

Виклад основного матеріалу. Тележурналіст - одна із найскладніших, найбільш динамічних професій, наголошуємо - педагогічних професій. Складність її пов'язана з високими вимогами, що ставляться до журналіста, керівника, педагога в умовах прискорення науково-технічного прогресу, зростання обсягу інфрормації, а також значних витрат розумової, психологічної енергії у творчовиховній діяльності. На нашу думку, роль педагогічного спілкування у журналістській роботі $є$ величезною, оскільки воно має можливість впливати на зміну структури та суті соціальних суб'єктів, на соціалізацію людини, становлення її як особистості.

Спілкування - процес взаємозв'язку і взаємодії суспільних суб'єктів (груп, осіб), у якому відбувається обмін інформацією, діяльністю, настроєм, досвідом, здібностями, умінням і навичками.

Серед різноманітності видів спілкування виділяють педагогічне спілкування. На нашу думку, педагогічне спілкування - це приватний вид спілкування людей (наприклад, у зіставленні з діловим, сімейним спілкуванням тощо). Иому властиві як загальні риси комунікативної взаємодії, так і суто специфічні, притаманні освітньому процесу. Можна стверджувати, що педагогічне спілкування $є$ одним із видів професійного спілкування .

Додамо до цього, що педагогічне спілкування як форма навчальної співпраці $є$ умовою оптимізації навчання і розвитку особистості тих, хто навчається.

Таким чином, педагогічне спілкування - це багатоплановий процес організації, встановлення і розвитку комунікації, взаєморозуміння і взаємодії між особистостями, педагогами і тими, що вчаться, породжуваний цілями і змістом їх спільної діяльності .

На нашу думку, воно спрямоване не тільки на саму взаємодію тих, що спілкуються, навчаються, з метою їх особистого розвитку, але є основним для самої педагогічної системи, для організацій засвоєння знань і формування на цій основі творчих умінь. Через це педагогічне спілкування характеризується, щонайменше, потрійною спрямованістю: на саму навчальну взаємодію, на тих, що навчаються (їх актуальний стан, перспективні лінії розвитку) і на предмет засвоєння. В той же час педагогічне спілкування визначається і потрійною орієнтованістю його суб'єктів: особистісною, соціальною і наочною.

Наприклад, НПП, працюючи з студентами над освоєнням якого-небудь навчального матеріалу, завжди орієнтує його результат на всіх присутніх в аудиторії i, навпаки,тележурналіст, працюючи 3 групою, тобто фронтально, впливає на кожного. Тому можна вважати, що своєрідність педагогічного спілкування, яке є сукупністю названих характеристик, виражається в органічному поєднанні елементів особистісно-орієнтованого, соціально орієнтованого і наочно орієнтованого навчання..

У процесі педагогічного спілкування ставляться і реалізуються комунікативні завдання, мета яких - передати знання і спонукати тих, хто спілкується, проявляє інтерес до певної проблеми, навчається до відповідних дій.

Аналізуючи соціальну роль педагогічного спілкування і його функції ми виділили наступне:

1. Взаємодія тележурналіста та аудиторії, НПП і студента полягає, насамперед, в обміні інформацією пізнавального афективно-оцінювального характеру. Передача цієї інформації здійснюєть- 
ся як вербальним шляхом, так і за допомогою різних засобів невербальної комунікації. Таким чином здійснюється інформаційна функція педагогічного спілкування.

2. Спілкування як діалог розгортається в умовах когнітивного складного віддзеркалення людьми один одного. Психологічно грамотне сприйняття тележурналіста аудиторії та викладачем студента допомагає встановити на цій основі взаєморозуміння і ефективну взаємодію. Мова йде в даному випадку про соціально-перцептивну функцію спілкування, про ті психологічні механізми (ідентифікації, емпатії, рефлексії), за допомогою яких сприймається і пізнається особистість тележурналіста.

3. Вступаючи у взаємини з аудиторією,тележурналіст, або ж викладач зі студентом пропонує себе як партнера по спілкуванню. Це припускає певну активність тележурналіста, як і науковопедагогічного працівника. Бажано, щоб він створив позитивне враження в очах аудиторії. Ця здатність суб'єкта спілкування фрормувати про себе позитивне враження отримала назву самоподачі, сучасніше б, на нашу думку, це можна назвати як самопрезентація. При педагогічному спілкуванні здійснюється презентація внутрішнього світу професійного тележурналіста, або ж викладача ВУЗу. У разі, коли викладач з багатим внутрішнім світом здатний грамотно представити його студентам, можна говорити про конгруентне самовираження. Конгруентність - це повна відповідність того, що людина пропонує за допомогою тону голосу, рухів тіла і голови, змісту його слів, внутрішніх переконань. Те, що людина говорить, знаходиться в повній гармонії зі всіма органами чуття, що виражають її стан.

4. У спілкуванні завжди відбувається взаємодія інтелекту людей, їх емоційно-вольової сфери, а це означає, що і в педагогічному спілкуванні фактично постійно розгортається взаємодія характерів і, зрозуміло, взаємодія особистостей. Все це знаходить своє відображення в інтерактивній функції педагогічного спілкування. Інтерактивна функція педагогічного спілкування полягає перш за все в організації взаємодії між тележурналістом і аудиторією, або ж викладачем і студентом, викладачем і групою, тобто в обміні не тільки знаннями та ідеями, але й діями.

5. Афректна фрункція спілкування полягає в емоційній стимуляції, розрядці, полегшенні, психологічному комфорті і контролі афекту, його нейтралізації, корекції або створенні соціально значущого афектного відношення. Позитивне емоційне, комфортне спілкування створює умови для творчої спільної діяльності, “ поведінки допомоги ”, особливої соціальної настанови на іншу людину, що викликає почуття пошани, вдячності, симпатії. В стані комфортного спілкування дві особи, наприклад, викладач і студент - починають утворювати якийсь загальний емоційно-психологічний простір (корпоративний), у якому розвивається процес залучення майбутнього спеціаліста до людської культури, різностороннього пізнання того, що оточує його у соціальній дійсності, і самого себе, своїх можливостей і здібностей, тобто розгортається процес подальшої соціалізації особистості майбутнього тележурналіста. Перераховані функції (інформаційна, соціально-перцептивна, презентативна, або самопрезентації, інтерактивна та афектна) можна назвати основними функціями педагогічного спілкування

На нашу думку, мистецтво тележурналіста виявляється в тому, як він знаходить контакти і потрібний тон спілкування з аудиторією, в тих чи інших ситуаціях; яким способом організовує їх самостійну роботу, включаючи їх у вирішення творчих задач; як він створює креативну атмосореру в студії; як він використовує свою уяву, інтуїцію, неусвідомлювані компоненти розумової активності .

Отже, творчість педагогічної взаємодії - це процес, у якому лектор, або ж педагог реалізує і затверджує свої потенційні сили і здібності і в якому він сам розвивається. Сучасна мистецька освіта потребує всебічно підготовлених педагогів, фахівців, які мають глибокі професійні знання та уміють виразити глибинну сутність своєї особистості для створення оптимальних соціально-педагогічних умов для розвитку майбутніх журналістов як професіоналів своєї справи і для гуманізації їх особистості.

Ми вважаємо, що для розвитку майбутніх журналістов, важливо, якими формами керівництва користуються педагоги, бо фрорми спілкування і взаємодії здійснюють істотний вплив на розвиток вихованців. Так вихованці “педагога-демократа" значно частіше проявляють прагнення до творчості, оригінальності, самостійності, комунікабельності, ніж ті, що виховуються в "автократа". Продуктивність демократичного стилю керівництва педагога позначається і на психологічному кліматі в аудиторії.

Форми спілкування, які відбивають рівень професійної культури викладача і зумовлені його віковими, психологічними особливостями, досвідом педагогічної діяльності у ВНЗ, $\epsilon$ досить динамічними. Вони вимагають постійного творчого підходу педагога до вибору способів спілкування. Адже від того, як складатимуться стосунки між студентами і викладачем, залежить у кінцевому рахунку ефективність підготовки майбутнього фахівця. Зрозуміло, що зробити це може лише той, хто сам володіє професійною майстерністю, хто здатний передати багатство людської культури своїм вихованцям .

Отже, продуктивність журналістської діяльності у системі творчої освіти багато в чому зумовлюється рівнем оволодіння технологією педагогічного спілкування, яке формує і корпоративну культуру майбутнього тележурналіста. Педагогічна діяльність взагалі неможлива без спілкування, і аналіз педагогічної практики показує, що багато серйозних утруднень у вирішенні проблем виникають через невміння педагога правильно організувати спілкування зі студентами. Які б класифікації методів виховання і навчання не пропонувалися, дія викладача вищої школи на особу студента здійснюється тіль- 
ки через його живе і безпосереднє спілкування з вихованцем.

На нашу думку, це свідчить про необхідність кожному педагогові поставити перед собою завдання осмислювати процес педагогічного спілкування і себе як особу, як професіонала в цьому процесі. Річ у тому, що оволодіння педагогічним спілкуванням шляхом проб і помилок утруднює роботу, негативно позначається на відношенні до професії, а деколи й веде до відмови від неї.

Спілкування викладача ВНЗ повинно постійно збагачуватися новими прийомами та засобами. Сутність педагогічного спілкування полягає в тому, що спілкування на різних рівнях (першокурсники, студенти старших курсів) вимагає від викладача постійної та обов'язкової адаптації (пристосування) при зміні умов до того чи іншого виду педагогічної діяльності. В кожному конкретному акті спілкування може змінюватися оцінка і самооцінка, концентрація уваги, рівень інтелектуальної активності, ступінь проникнення в зміст пропонованого матеріалу лекції. Одне із основних умінь викладача - розповісти про складне явище дохідливо, просто, чітко, послідовно, що є важливим фактором культури педагога вищої школи.

Отже, для формування корпоративної культури тележурналіста професійна діяльність вимагає від викладача максимального терпіння, наполегливості, послідовності у діях, принциповості, поєднаних із тактовністю і гнучкістю, самодисципліною.

Існує думка, що багато журналістів не завжди правильно визначають і вирішують комунікативні завдання, оскільки подібні уміння не формуються у них під час навчання у ВНЗ. Це підтверджується нашими спостереженнями. Тому ми вважаємо, що при формуванні корпоративної культури ця її складова заслуговує особливої уваги.

Педагогічне спілкування виконує такі фрункції:

- взаємопізнання вихователя і вихованця;

- обмін між ними думками, почуттями та інформацією;

- організація і здійснення різноманітних та багатогранних навчально-виховних заходів;

- самовираження, самовизначення і самоутвердження учасників цього процесу.

Характер спілкування вихователя з вихованцем визначає основні стилі його роботи. Виокремлюють авторитарний, демократичний і ліберальний стилі взаємодії суб'єктів навчання. Авторитарний стиль роботи характеризується жорсткою фрормою управління взаємодією учасників навчальновиховного процесу за допомогою наказів, вказівок, інструкцій тощо. Цей стиль з точки зору гуманізації та демократизації європейської і світової освіти вважається абсолютно неприйнятним, оскільки порушує права особистості.

- Демократичний стиль виявляється в опорі педагога на навчальний колектив, у намаганні зацікавити вихованців навчально-пізнавальною діяльністю, у заохоченні їх ініціативи та самостійності.

Ліберальний стиль характеризується самоусуненням педагога від відповідальності за хід і результати навчально-виховних заходів, формалізмом, потуранням і анархізмом. Найбільш оптимальним, в той же час найскладнішим стилем, безперечно, є демократичний.

У педагогічному спілкуванні дуже яскраво виражений психологічний аспект. Щоб зробити спілкування виховно-ефективним, журналіст повинен розбиратися в психології певної аудиторії, адекватно емоційно реагувати на їх поведінку і психічний стан, враховувати при виборі способу спілкування їх індивідуальні особливості. Тому психологічна складова аксіологічного компонента моделі структури корпоративної культури журналіста повинна обов'язково включати психологічні складові, які в процесі її формування мають корелюватися. Не можна не погодитися з тим, що максимальний ступінь успіху педагогічної діяльності забезпечується діалогічним і довірчим типами спілкування. При цьому треба не забувати про етичний бік спілкування, обов'язкове звернення до таких моральних цінностей, як доброта, справедливість, совість, чесність, ввічливість, коректність тощо. Довіра, свобода, розкутість, відсутність страху, радісне ставлення до викладача й учня, прагнення до доброзичливого взаєморозуміння в навчальній групі тощо - результат правильного спілкування викладача зі студентами. Грубість, сарказм, неповажне ставлення до студентів, що виявляється в стилі поведінки науково-педагогічного працівника і його зверненні, зводять нанівець всю систему навчання, як би змістовно і методично правильно вона не була організована, а також викривлюють корпоративну культуру майбутнього фрахівця. Отже, відмічені якості і визначають зону педагогічної дії в процесі формування корпоративної культури тележурналістів в тій її частині, яка співвідноситься з морально-етичною стороною спілкування науково-педагогічних працівників і майбутніх митців.

\section{תimepamypa}

1. Адаир Д. Психология лидерства. Москва : Изд-во Эксмо, 2006. 352 с.

2. Амонашвили Ш. А. Психологические основы педагогики сотрудничества : [книга для учителя] Киев: Освіта, 1997. 62 с.

3. Бабанский Ю. К. Оптимизация педагогического процесса. Київ : Рад. школа, 1984. С. 5-204.

4. Бабанский Ю. К. Энциклопедия педагогического процесса в вопросах и ответах. Київ : Рад. шк., 1984.

5. Балл Г. О. Неперервна професійна освіта: проблеми, пошуки, перспективи : монографія // Гуманізація загальної та професійної освіти : суспільна актуальність і психолого-педагогічні орієнтири. Київ : Віпол, 2000. C. 134-157. 
6. Балл Г. О. Парадигма діалогу і проблема прилучення до наукової культури // Професійна освіта : педагогіка і психологія : Українсько-польський щорічник / за ред. Т. Левовицького, І. Зязюна, І. Вільш, Н. Ничкало. Ченстохова-Київ, 1999. 341с. 1997. 108 c..

7. Зязюн І. А. Краса педагогічної дії : навч. посіб. Київ : Українсько-фінський ін-т менеджменту і бізнесу,

8. Зязюн І. А. Педагогічна майстерність як мистецька дія : посіб. для вчителів (Книжка в журналі) // Рідна школа. 1995. №7

9. Кан-Калик В. А. Педагогическое творчество. Москва : Педагогика, 1990. С.360

10. Леонтьев А. А. Педагогическое общение. Москва : Нальчик, 1979. 256 с.

11. Педагогічна майстерність : хрестоматія : навч. посіб. / [упоряд. : І. А. Зязюн, Н. Г. Базидевич, Т. Г. Дмитренко та ін. ; за ред. І. А.Зязюна]. Київ : Вища шк., 2006. 606 с.

12. Савенкова Л. О. "Комунікативна атака" у формуванні навичок педагогічного спілкування // Педагогіка і психологія. 1998. № 4. С. 101.

13. Debesse V. Traite des sciences pedagogiques. Paris : PUF, 1974. P. 50-54.

\section{References}

1. Adair, D. (2006) .Psychology of leadership. Moscow: Exmo Publishing House [in Russian].

2. Amonashvili ,S.A. ( 1997).Psychological bases of pedagogy of cooperation: [book for teacher] Kiev: Education [in Ukrainian].

3. Babansky ,Yu. (1984). Optimization of the pedagogical process. Kiev: Glad. School, P. 5-204 [in Ukrainian].

4. Babanskiy, Yu. K. (1984). Encyclopedia of the pedagogical process in questions and answers. Kiev: Glad. Shk [in Ukrainian].

5. Ball,G.O. (2000). Continuing professional education: problems, searches, prospects: monograph. Humanization of general and professional education: social relevance and psychological and pedagogical guidelines. Kyiv: Vipol, 134-157 [in Ukrainian].

6. Ball, G.O. (1999).The Paradigm of Dialogue and the Problem of Attraction to Scientific Culture // Professional Education: Pedagogy and Psychology: Ukrainian-Polish Annual / ed. T. Levovitsky, I. Ziazun, I. Will, N. Nichkalo. Czestochowa-Kyiv [in Ukrainian].

7. Ziazun, I.A. (1997). The beauty of pedagogical action: textbook. tool. Kyiv: Ukrainian-Finnish Institute of Management and Business [in Ukrainian].

8. Ziazun, I.A. (1995). Pedagogical mastery as an artistic action: a tool. for teachers (Book in journal) // Native School, 7 [in Ukrainian].

9. Kahn-Kalik,V.A. (1990).Pedagogical creativity. Moscow: Pedagogy [in Russian].

10. Leontiev A.A. (1979). Pedagogical communication. Moscow: Nalchik, [in Ukrainian].

11. Pedagogical skills: Readers: Teach. tool. (2006). Kyiv: Higher School [in Ukrainian].

12. Savenkova L..O. (1988). "Communicative attack" in the formation of pedagogical communication skills. Pedagogy and psychology, 4, 101 [in Ukrainian].

13. Debesse, V. (2006). Traite des sciences pedagogiques. Paris: PUF, 1974. R. 50-54. 1. Adair D. Psychology of leadership. Moscow: Exmo Publishing House [in Russian].

Стаття надійшла до редакції 23.05.2019 p. 